\title{
Heterologous expression of abaecin peptide from Apis mellifera in Pichia pastoris
}

\author{
Denis Prudencio Luiz ${ }^{1 *}$, Juliana Franco Almeida², Luiz Ricardo Goulart² ${ }^{2}$ Nilson Nicolau-Junior ${ }^{1}$ \\ and Carlos Ueira-Vieira ${ }^{1}$
}

\begin{abstract}
Background: Antimicrobial peptides (AMPs) are the first line of host immune defense against pathogens. Among AMPs from the honeybee Apis mellifera, abaecin is a major broad-spectrum antibacterial proline-enriched cationic peptide.

Results: For heterologous expression of abaecin in Pichia pastoris, we designed an ORF with HisTag, and the codon usage was optimized. The gene was chemically synthetized and cloned in the pUC57 vector. The new ORF was subcloned in the PPIC9 expression vector and transformed into P. pastoris. After selection of positive clones, the expression was induced by methanol. The supernatant was analyzed at different times to determine the optimal time for the recombinant peptide expression. As a proof-of-concept, Escherichia coli was co-incubated with the recombinant peptide to verify its antimicrobial potential.
\end{abstract}

Discussion: Briefly, the recombinant Abaecin (rAbaecin) has efficiently decreased E. coli growth $(P<0.05)$ through an in vitro assay, and may be considered as a novel therapeutic agent that may complement other conventional antibiotic therapies.

Keywords: Abaecin, Proline-rich antimicrobial peptide, Heterologous expression, Pichia pastoris, Apis mellifera

\section{Background}

Insects have cellular and humoral defenses in the innate immunological system. The circulating hemocytes are responsible for the first, as in phagocytosis cases and pathogens nodulation [1,2] and the production of peptides by the fat bodies related to the second [3].

The antimicrobial peptides (AMPs) are molecules present in the immune system of multinuclear organisms, acting in the defense against invaders such as gram-positive, gram-negative bacteria and fungi [4].

The abaecin peptide, found in Apis mellifera, is one of the largest proline-rich antimicrobial peptide, with 34 amino acids containing 10 prolines (29\%) and no cysteine residues. The total charge is $4^{+}$, grouped within positions $12,13,27$, and 29. Prolines are uniformly distributed

\footnotetext{
*Correspondence: prudenis@yahoo.com.br

${ }^{1}$ Genetics Laboratory, Institute of Genetics and Biochemistry, Federal University of Uberlândia, 1720 Pará, Uberlândia, MG 38400902, Brazil Full list of author information is available at the end of the article
}

through the peptide length, preventing the $\alpha$-helical conformation [5, 6].

The yeast Pichia pastoris is methylotrophic, which means a capacity of using the methanol as its only carbon source. The yeast oxidizes the methanol producing formaldehyde and hydrogen peroxide, using oxygen molecules and alcohol oxidase enzymes. The yeast produces large quantity of this enzyme, due to its low affinity to oxygen, being regulated by the alcohol oxidase 1 promoter (AOX1). The AOX1 promoter within the vector, induced by methanol, leads to expression of the gene of interest at high levels. The protein expression using the pPIC9 vector occurs in an extracellular manner, decreasing the steps between expression and obtaining the peptide of interest $[7,8]$.

Antimicrobial peptides were isolated from many kind of organism like vertebrates and invertebrates animals, plants, bacteria, fungi, viruses and artificially synthesized in laboratory for experiments [9]. However, our aim was to construct a synthetic gene to express the abaecin 
peptide from A. mellifera in P. pastoris. Our purpose was to optimize the expression of this recombinant antimicrobial peptide with biological effects, leading to a possible new drug development.

\section{Methods}

\section{Gene design and synthesis}

The recombinant peptide coding sequence was designed based on the deposited sequence in the National Center for Biotechnology Information (NCBI) NP_001011617.1, of A. mellifera's abaecin peptide. Some nucleotides sequences were added to facilitate cloning and optimization of this protein expression in yeast $P$. pastoris. Two restriction sites were added: in the $5^{\prime}$ position for EcoRI enzyme, and another one in $3^{\prime}$ position for NotI enzyme. It was also added hexahistidine-tag (Histag) for expression confirmation process, and a stop codon was included as well. The peptide signal of the entire abaecin sequence was not used.

The sequence was optimized with the following parameters: length: 129, GC\%: 45.08, GAATTC-TACGTTCC ATTGCCTAACGT TCCACAACCTGGTAGAAG ACCATTTCCTACT T TCCCAGGTCAAGGACC TTTTAACCCTAAGATTAAATGGCCTCAGGGAT ATCGTCGACATCACCATCACCATCACTAA-GCGG CCGC, therefore, the new abaecin sequence was deduced: YVPLPNVPQPGRRPFPTFPGQGPFNPKIKWPQGYHHHHHH. Then, to optimize the sequence for $P$. pastoris, the codon adaptation index (CAI) was used. It measures the extension level of differential usage of codons in highly expressed genes [10]. The measurements in this technique use the OptimumGeneTM (GenScript ${ }^{\circledR}$ Corporation) software.

After analysis and deduction of the optimized DNA sequence, the chemical synthesis of the minigene was performed, cloned in pUC57, and sequenced for confirmation (GenScript ${ }^{\circledR}$ Corporation).

\section{Sub-cloning of the synthetic gene in the expression vector pPIC9}

The insert was removed from vector pUC57 using the NotI and EcoRI enzymes. The vector pPic9 was also digested with the same enzymes, quantified and dephosphorylated with SAP enzyme. It was used $16.7 \mathrm{ng}$ of the insert in the ligation reaction with $50 \mathrm{ng}$ of pPIC9 vector and $1 \mathrm{U}$ of the DNA ligase I (Invitrogen) at $14{ }^{\circ} \mathrm{C}$ overnight. The product of this reaction was named pPic9abacin, confirmed by electrophorese at $0.8 \%$ of agarose. The Escherichia coli Top10 bacteria were transformed with the pPic9abaecin by electroporation in $0.2 \mathrm{~cm}$ cuvette with lysogeny broth (LB), following the parameters: $2.5 \mathrm{kV}, 200 \Omega$ and $25 \mu \mathrm{F}$, electroporated in Bio-Rad Gene Pulser (Bio-Rad). These clones were cultivated in LB medium containing $50 \mu \mathrm{g} / \mathrm{mL}$ of Ampicillin. The plasmid extraction was performed using QIAprep $^{\circledR}\left(\right.$ Qiagen $\left.^{\circledR}\right)$, following the kit protocol.

\section{Transformation and electroporation of Pichia}

The recombinant plasmid was linearized with SacI enzyme (FastDigest, Fermentas) $1 \mu \mathrm{L} / \mu \mathrm{g}$ (enzyme/DNA), purified with phenol/chloroform/125:24:1 and used to transform the strain GS115 P. pastoris yeast. The GS115 strain was cultivated in $50 \mathrm{~mL}$ of yeast extract peptone dextrose (YPD, $1 \%$ yeast extract, $2 \%$ peptone and $2 \%$ dextrose) at $30^{\circ} \mathrm{C}$ overnight, then inoculated $0.5 \mathrm{~mL}$ of this culture in $500 \mathrm{~mL}$ of fresh YPD at $30{ }^{\circ} \mathrm{C}$ overnight until $\mathrm{OD}_{600}=1.3-1.5$. The cells were centrifuged at $1500 \times g$ for $5 \mathrm{~min}$ at $4{ }^{\circ} \mathrm{C}$ and resuspended, for each of the followed steps: 500 and $250 \mathrm{~mL}$ sterilized water, then in 20 and $1 \mathrm{~mL}$ of sorbitol $1 \mathrm{M}$, all processes realized in icecold. The transformation system of $10 \mu \mathrm{g}$ of linearized DNA in $10 \mu \mathrm{L}$ TE Buffer (10 mM Tris-HCl, 1 mM EDTA, $\mathrm{pH} 8.0)$ and $80 \mu \mathrm{L}$ of competent $P$. pastoris cells was incubated in ice-cold electroporation cuvette of $0.2 \mathrm{~cm}$ for $5 \mathrm{~min}$ in ice. The electroporation followed the parameters of $1.5 \mathrm{kV}, 200 \Omega$ and $25 \mu \mathrm{F}$, cells were immediately incubated with $1 \mathrm{~mL}$ of $1 \mathrm{M}$ sorbitol and spread $200 \mu \mathrm{L}$ of aliquots on RDB plates (regeneration dextrose base, 9.3:1 sorbitol/agar, w/w) without histidine. The plates were incubated at $30{ }^{\circ} \mathrm{C}$ until colonies appear [8]. The transformation was confirmed by PCR and electrophorese in agarose gel $1.5 \%$ of the clones.

\section{Expression of the recombinant peptide}

A recombinant colony was inoculated in buffered minimal glycerol (BMG) medium containing $100 \mathrm{mM}$ potassium phosphate, $\mathrm{pH} 6.0,1.34 \%(\mathrm{w} / \mathrm{v})$ of yeast nitrogen base (YNB), $4 \times 10^{-5} \%(\mathrm{w} / \mathrm{v})$ of biotin, and $1 \%$ glycerol, for two days at $28{ }^{\circ} \mathrm{C}$. Then, the cells were centrifuged and re-suspended in buffered minimal methanol (BMM) medium, composed of $100 \mathrm{mM}$ of potassium phosphate, $\mathrm{pH} 6.0,1.34 \%(\mathrm{w} / \mathrm{v}) \mathrm{YNB}, 4 \times 10^{-5} \%(\mathrm{w} / \mathrm{v})$ biotin, and methanol $0.5 \%$, in order to avoid the action of proteases [11]. at the optical density $\mathrm{OD}_{600}=1.0$, under the temperature of $28^{\circ} \mathrm{C}$, at $250 \mathrm{rpm}$.

To better verify the induction time of expression rates, supernatants were collected at times $0,6,12,24,36$, $48,60,72$ and 96 (h) with the addition of $0.5 \%(\mathrm{w} / \mathrm{v})$ of methanol at times $0,24,48$ and 72 (h). The expression confirmation was analyzed by Tricine-SDS-PAGE electrophoresis [12], and silver-stained.

\section{Growth inhibition test}

The inhibition test was done in 96-well microtiter plate containing, in the first row, $200 \mu \mathrm{L}$ of $\mathrm{LB}$, as negative control. A mix containing $200 \mu \mathrm{L}$ of LB with E. coli DH5 $\alpha$, in 
an $\mathrm{OD}_{595}=0.3$, was added in the second row as first positive control (only E. coli). In the third, fourth and fifth rows was added $200 \mu \mathrm{L}$ of LB with $E$. coli and new lyophilized BMM medium in quantities of 1,10 and $25 \mu \mathrm{g}$, respectively, control for supernatant without recombinant peptide (named BMM). In the sixth, seventh and eighth rows were added $200 \mu \mathrm{L}$ of LB with $E$. coli and BMM medium with abaecin in quantities of 1,10 and $25 \mu \mathrm{g}$, respectively. The test was run in quadruplicated and the average of OD values from the negative control were subtracted from all wells.

\section{Abaecin peptide modeling}

The abaecin peptide was modeled by ab initio method, which is used when there is little or no initial information about the molecule structure in the data banks. The Rosetta 3.5 software [13], specifically the protocol of the AbinitioRelax software [14-19] was used to this goal. Approximately 2000 models were generated, one being selected after evaluation and validation using the dDFIRE [20]. The dDFIRE generates a score based on the free energy of the structure, therefore we select, among the thousands of models, one who has minor free energy. The peptide was visualized using the Chimera 1.1 software [21], where views of surface of the Coulombic electrostatic potential and amino acids hydrophobicity were generated.

\section{Statistical analysis}

The data obtained was analyzed using the Prism 4.0 software (GraphPad, San Diego, CA). After verification of data distribution, it was used analysis of variance for repeated variables, and Bonferroni tests to compare the obtained $\mathrm{p}$ value $(P<0.05)$.

\section{Results}

Gene design and synthesis and codon optimization

After the deduction and optimization of the new gene sequence, the abaecin of $A$. mellifera and the modified abaecin sequences were aligned by Clustal W software to check the non-modified regions and the optimized codons. The chemically synthesized gene of abaecin, with the size of $143 \mathrm{bp}$, was cloned into pUC57 clone vector.

\section{Expression of recombinant peptide}

The colonies of $P$. pastoris transformed with pPic9abaecin were grown in BMG medium for development and then in BMM for expression. Supernatants were collected from the expression medium in different times (Fig. 1). At times T3 (72 h) and T4 (96 h), it is possible to visualize the $5.2 \mathrm{kDa}$ band showing that the selected colony produced the isolated peptide, not excluding the possibility of also containing peptides in the truncated form.

\section{Inhibition growth test}

Due to non-purification of the peptide in the present study, we adapted the antibiogram assay using the crude expression supernatant. After the confirmation of the production of recombinant peptide, the supernatant containing peptide was lyophilized and tested in E. coli culture in 96-well microtiter plate for antimicrobial activity confirmation.

The test showed that the quantities of 10 and $25 \mu \mathrm{g}$ of lyophilized medium, containing the recombinant peptide, was sufficient to significantly inhibit the $E$. coli growth after $24 \mathrm{~h}$ treatment (Fig. 2b, c). There was no interference in the abaecin peptide inhibition by the

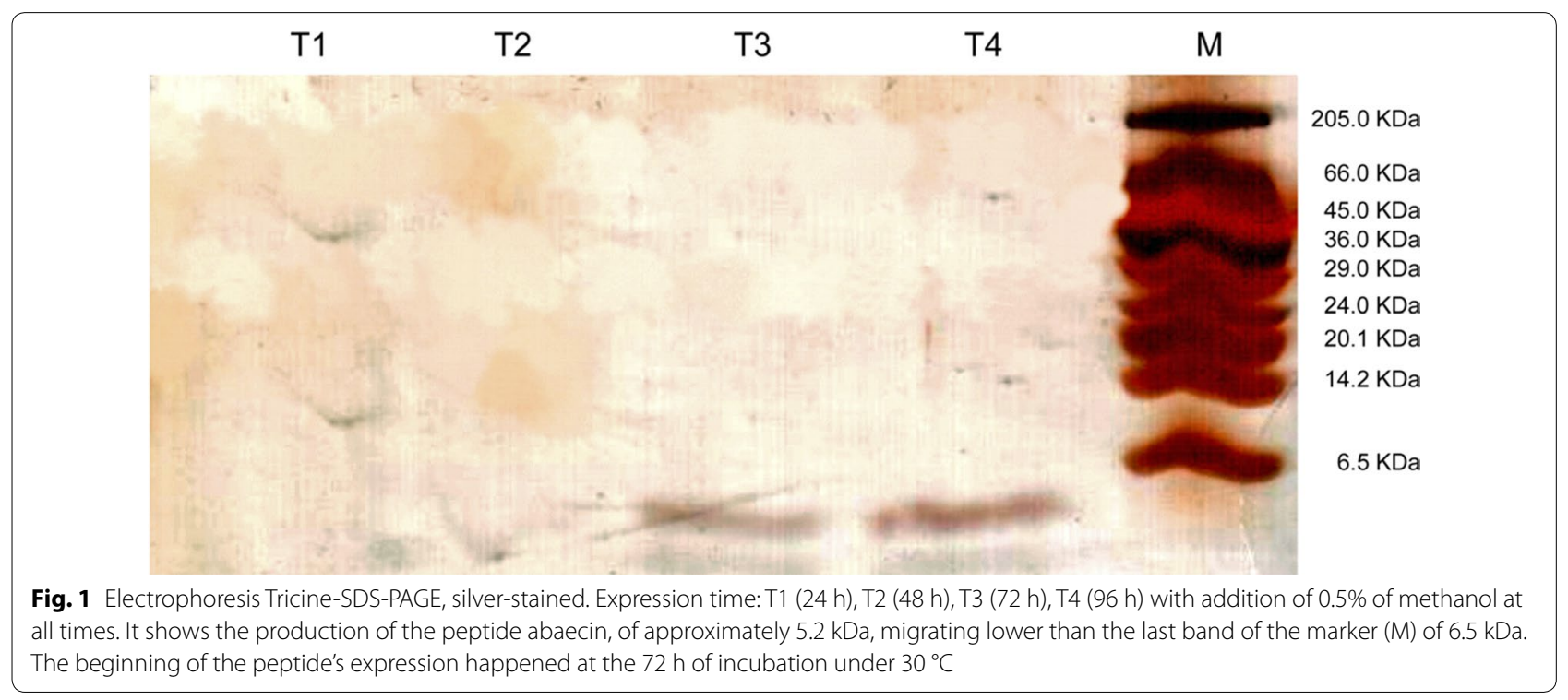



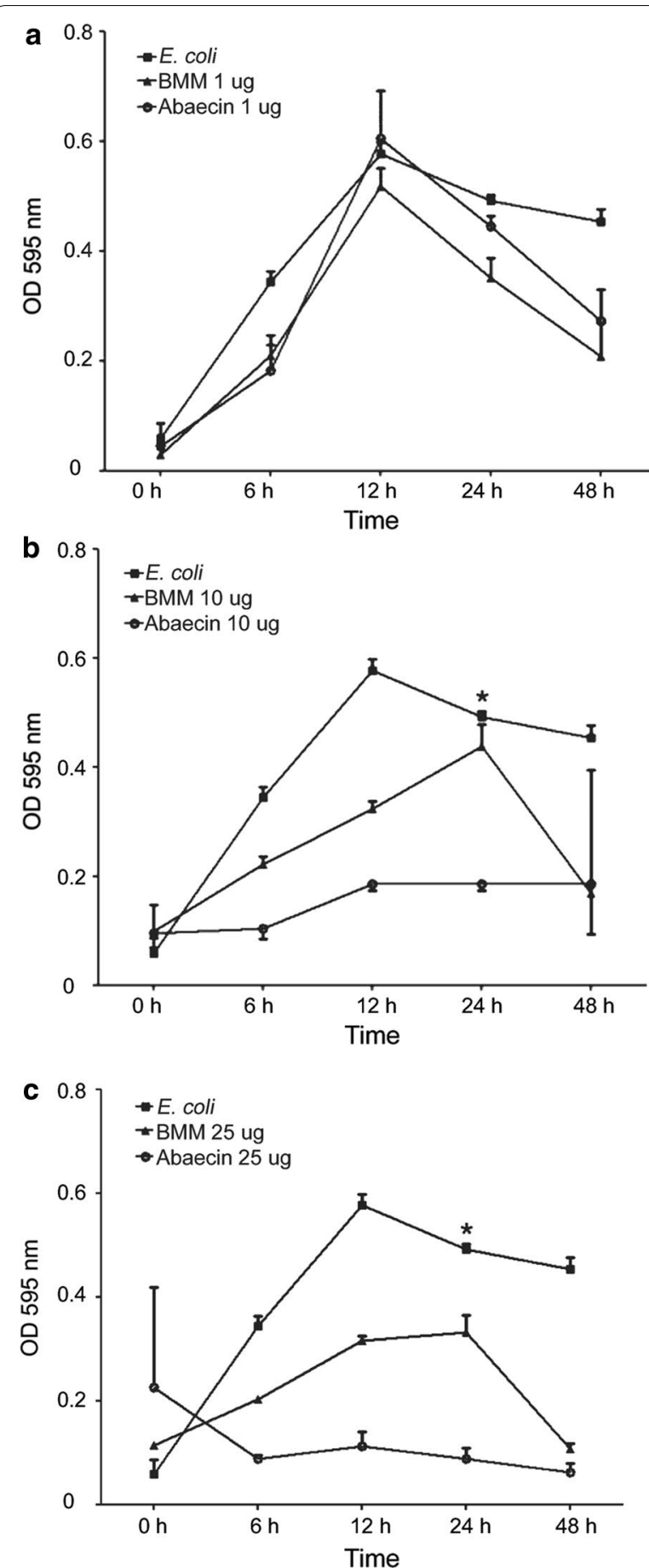

Fig. 2 Graphics of optical density (OD) measurements by time in the analyzed wells. Square E. coli (first positive control); triangle BMM (LB with E. coli and new lyophilized BMM medium without recombinant peptide); and circle abaecin (LB with E. coli and BMM medium with recombinant abaecin). The graphics $\mathbf{a}-\mathbf{c}$ show three different quantities of lyophilized BMM medium with and without abaecin, 1, 10 and $25 \mu \mathrm{g}$, respectively. ${ }^{*}$ Significant difference compared to BMM sample $(P<0.01$, Bonferroni test) and abaecin $(P<0.001$, Bonferroni test $)$ at time $24 \mathrm{~h}$ lyophilized BMM medium. The quantity of $1 \mu \mathrm{g}$ did not inhibit bacterial growth (Fig. 2a).

The statistical test showed significant difference in rAbaecin activity in relation to controls (E. coli and BMM only). It presented antibacterial activity in concentrations of 10 and $25 \mu \mathrm{g}$, respectively, after time 12 , accentuating after $24 \mathrm{~h}$.

\section{Abaecin structure}

The peptide sequence optimized abaecin (43 aas + histag) showed a $\alpha$-helix structure in C-terminal portion composed by (KWPQGYHHHHHH) residues in red on structural analyses. The views of surface of the Coulombic electrostatic potential and amino acids hydrophobicity showed in (Fig. 3). This conformation suggests an interaction with the bacterial membrane.

\section{Discussion}

The antimicrobial effect of peptides, and their production, has been studied in the immunological system of animals, such as bees. A study on the bee specie Bombus pascuorum identified four types of antimicrobial peptides: defensin, hymenoptaecin, apidaecin and abaecin. These peptides were directly extracted from the animal's hemolymph, which were purified and tested in bacterial culture, presenting antimicrobial activity [22].

In wasps from the specie Pteromalus puparum an abaecin cDNA was identified. The protein was chemically synthetized and tested in E. coli culture using this cDNA sequence, showing inhibitory activity, and no hemolytic activity was shown [23].

Previous DNA recombination methods were heavily used to high levels of peptide expression [24, 25]. For a long time, the system of proteins expression by $E$. coli was used due to its easy maintenance and fast culture growth [26]. It was not possible to use $E$. coli as an expression system because the recombining product is toxic to the bacteria. Because of that, the $P$. pastoris expression system was used.

The $P$. pastoris yeast, being a eukaryote, has advantages in the protein expression and processing, being able to make post-translational modifications. Another great advantage is the fact that, it is easier to manipulate when compared to both E. coli and Saccharomyces cerevisiae expression. The methodology used is also faster and cheaper compared to other expression systems like baculovirus or other culture tissues, allowing a high expression index $[8,27,28]$.

The use of $P$. pastoris yeast has been used as an important protein expression method. Studies of antimicrobial peptides based on shrimp [29], butterfly, frog [30], Drosophila melanogaster, spine soldier bug [31] and human [32] genes have proven the effectiveness of this system for the production of these peptides without affecting 


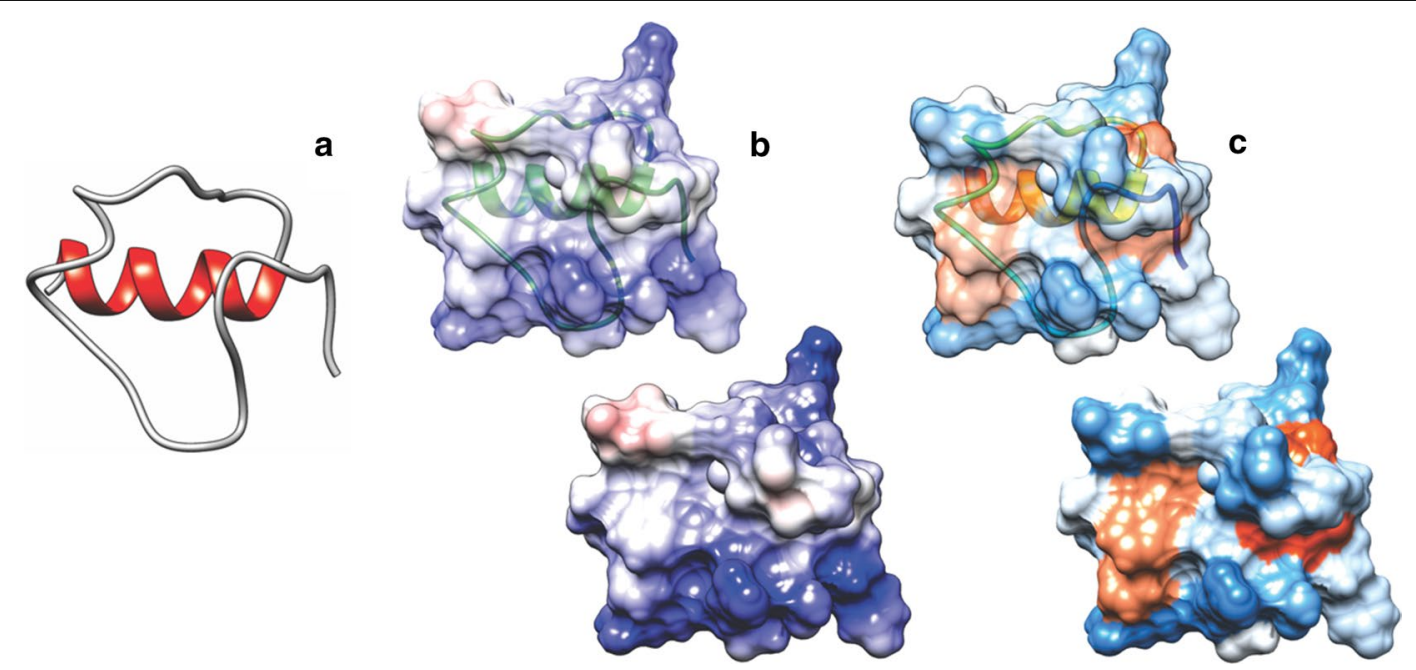

Fig. 3 Structural analysis of the heterologous peptide. In a structure abaecin with a-helix in red, in $\mathbf{b}$ analysis of electrostatic surface: positive charges in blue and negative charges in red, and chydrophobicity surface analysis, warmer colors indicate hydrophobic regions

their inhibitory activity. Here we describe a production of recombinant abaecin (from A. mellifera) in P. pastoris host.

The chemical synthesis of the abaecin gene from $A$. mellifera, to express the peptide in P. pastoris yeast, allowed the production of the antimicrobial peptide. This system, which has shown capacity of a fast production and easy maintenance, can be used to deliver the expected results. The use of pPIC9 vector of expression allowed the peptide to be expressed in an extracellular way, reducing the number of steps in the manipulation methodology. By using the expression optimization, it was possible to estimate the necessary time for the production.

In order to the abaecin peptide be tested in E. coli samples, the optimum incubation period was $24 \mathrm{~h}$. After this time the OD of the analyzed samples decreases, supposedly because bacterial growth reaches a high concentration, causing bacterial death due to the lack of supply and low environmental conditions in the culture mediums [33]. The treated samples with the abaecin in the lyophilized BMM medium peptide at $10 \mu \mathrm{g}$, showed an antibacterial activity after $12 \mathrm{~h}$ keeping an OD lower than 0.2 . On the other hand, the sample treated with $25 \mu \mathrm{g}$ showed antibacterial activity profile between 6 and $12 \mathrm{~h}$ with an OD close to 0.1 (Fig. 2).

The antibacterial activity depend on the hydrophobicity and the structural ability to assume an amphipathic helical conformation $[34,35]$. Other patterns affect the potency and spectrum of the AMPs $\alpha$-helix, such as sequence, charge and amphipathicity. These features are interrelated and they are the key for the development of more potent AMPs with a straight action [36, 37].
Antimicrobial peptides with more than 20 aas proline rich, like abaecin, showed effectiveness against grampositive bacteria and fungi [38-40]. In another study, the chemically synthetized abaecin peptide, based on B. pascuorum, didn't show any effect without the aid of another peptide. When combined with other peptide, it exhibited action against $E$. coli growth [41]. Our heterologous abaecin, expressed in the P. pastoris system, showed antibacterial activity without the use of another AMP.

The charge of the proline-rich AMPs peptides (verified by in silico modeling) may provide the crossing of the membrane cell in non-lytic manner, interacting with proteins from the cytoplasm of the bacterium hampering protein synthesis [42]. This process shortens the quantity of the total bacteria in the samples, showed by the decreasing levels of the OD in the reading $595 \mathrm{~nm}$ in the test (Fig. 2).

It was shown that the methodology used facilitated the results of the proposed study. The chemical synthesis based in the sequence of the abaecin gene of A. mellifera, and optimized to P. pastoris (pPic9abaecin) proved to be efficient inside the expression system. The pPIC9 vector was of great importance to simplify the steps of the process, enabling it to obtain the peptide abaecin in the supernatant expression medium. The rAbaecin expressed in a heterologous manner at time $72 \mathrm{~h}$, showing that there is an inhibition variation of microbial growth of $E$. coli DH5 $\alpha$ bacteria within both time 6, 12 and $24 \mathrm{~h}$.

Further studies are needed to the large-scale production and purification of this compound, in order to produce an antibiotic with such elements.

This results also shows that the heterologous abaecin peptide has antimicrobial activity against $E$. coli, and have 
biotechnological potential for the production of new antimicrobial drug, which acts against bacteria resistance to current drugs.

\author{
Abbreviations \\ AMP: antimicrobial peptides; AOX 1: alcohol oxidase 1 promoter; pPic9aba- \\ cin: pPIC9 vector-insert; rAbaecin: recombinant abaecin; YPD: yeast extract \\ peptone dextrose; RDB: regeneration dextrose base; BMG: buffered minimal \\ glycerol; YNB: yeast nitrogen base; BMM: buffered minimal methanol.
}

\section{Authors' contributions}

CUV and JFA designed the experiments, DPL and JFA conducted most of the experiments. NNJ modeled the peptide structure. DPL assayed the recombinant protein expression and growth inhibition test. DPL wrote this manuscript and CUV, LRG and JFA helped to revise. All authors read and approved the final manuscript.

\section{Author details}

1 Genetics Laboratory, Institute of Genetics and Biochemistry, Federal University of Uberlândia, 1720 Pará, Uberlândia, MG 38400902, Brazil. ${ }^{2}$ Nanobiotechnology Laboratory, Institute of Genetics and Biochemistry, Federal University of Uberlândia, 1720 Pará, Uberlândia, MG 38400902, Brazil.

\section{Acknowledgements}

We would like to express our gratitude to all staff from the Laboratory of Biochemistry and Animal Toxins (LaBiTox) and Nanobiotechnology Laboratory at UFU for the support and availability of the equipment used.

\section{Competing interests}

The authors declare that they have no competing interests.

\section{Funding}

This work was supported by the Coordination of Improvement of Higher Education Personnel (CAPES); National Counsel of Technological and Scientific Development (CNPq, Grant Number 445679/2014-0) and Minas Gerais State Research Foundation (Fapemig).

\section{Publisher's Note}

Springer Nature remains neutral with regard to jurisdictional claims in published maps and institutional affiliations.

Received: 22 November 2016 Accepted: 21 April 2017

Published online: 03 May 2017

\section{References}

1. Jiravanichpaisal P, Lee BL, Söderhäll K. Cell-mediated immunity in arthropods: hematopoiesis, coagulation, melanization and opsonization. Immunobiology. 2006:211:213-36.

2. Strand MR. The insect cellular immune response. Insect Sci. 2008;15:1-14.

3. Arrese EL, Soulages JL. Insect fat body: energy, metabolism, and regulation. Annu Rev Entomol. 2010;55:207-25.

4. Izadpanah A, Gallo RL, Diego S. Antimicrobial peptides. J Am Acad Dermatol. 2005:52:381-90.

5. Chou PY, Fasman GD. Prediction of the secondary structure of proteins from their amino acid sequence. Adv Enzymol Relat Areas Mol Biol. 1978;47:45-148

6. Xu P, Shi M, Chen X-X. Antimicrobial peptide evolution in the Asiatic honey bee Apis cerana. PLoS ONE. 2009;4:e4239.

7. Romanos MA, Scorer CA, Clare JJ. Foreign gene expression in yeast: a review. Yeast. 1992;8:423-88.

8. Pichia Expression Kit, for expression of recombinant proteins in Pichia pastoris, Catalog No. K1710-01 [Internet]. 2014. p. 98. Available from: https:// tools.thermofisher.com/content/sfs/manuals/pich_man.pdf. Accessed 5 Apr 2017.
9. Alves D, Olívia Pereira M. Mini-review: antimicrobial peptides and enzymes as promising candidates to functionalize biomaterial surfaces. Biofouling. 2014;30:483-99.

10. Sharp PM, Li WH. The codon adaptation index-a measure of directional synonymous codon usage bias, and its potential applications. Nucleic Acids Res. 1987;15:1281-95.

11. Clare JJ, Romanes MA, Rayment FB, Rowedder JE, Smith MA, Payne MM, et al. Production of mouse epidermal growth factor in yeast: high-level secretion using Pichia pastoris strains containing multiple gene copies. Gene. 1991;105:205-12.

12. Schagger H. Tricine-SDS-page. Nat Protoc. 2006;1:16-22.

13. Rohl CA, Strauss CEM, Misura KMS, Baker D. Protein structure prediction using Rosetta. Methods Enzymol. 2004;383:66-93.

14. Raman S, Vernon R, Thompson J, Tyka M, Sadreyev R, Pei J, et al. Structure prediction for CASP8 with all-atom refinement using Rosetta. Proteins Struct Funct Bioinforma. 2009:77:89-99.

15. Bradley P, Misura KMS, Baker DB. Toward high-resolution de novo structure prediction for small proteins. Science. 2005;309:1868-71.

16. Bonneau R, Strauss CEM, Rohl CA, Chivian D, Bradley P, Malmström L, et al. De novo prediction of three-dimensional structures for major protein families. J Mol Biol. 2002;322:65-78.

17. Bonneau R, Tsai J, Ruczinski I, Chivian D, Rohl C, Strauss CEM, et al. Rosetta in CASP4: progress in ab initio protein structure prediction. Proteins Struct Funct Genet. 2001;45:119-26.

18. Simons KT, Ruczinski I, Kooperberg C, Fox BA, Bystroff C, Baker D. Improved recognition of native-like protein structures using a combination of sequence-dependent and sequence-independent features of proteins. Proteins Struct Funct Genet. 1999;34:82-95

19. Simons KT, Kooperberg C, Huang E, Baker D. Assembly of protein tertiary structures from fragments with similar local sequences using simulated annealing and Bayesian scoring functions. J Mol Biol. 1997;268:209-25

20. Yang Y, Zhou Y. Specific interactions for ab initio folding of protein terminal regions with secondary structures. Proteins Struct Funct Genet. 2008;72:793-803.

21. Pettersen EF, Goddard TD, Huang CC, Couch GS, Greenblatt DM, Meng EC, et al. UCSF chimera-a visualization system for exploratory research and analysis. J Comput Chem. 2004;25:1605-12.

22. Rees JA, Moniatte M, Bulet P. Novel antibacterial peptides isolated from a European bumblebee, Bombus pascuorum (Hymenoptera, apoidea). Insect Biochem Mol Biol. 1997;27:413-22.

23. Shen X, Ye G, Cheng X, Yu C, Altosaar I, Hu C. Characterization of an abaecin-like antimicrobial peptide identified from a Pteromalus puparum cDNA clone. J Invertebr Pathol. 2010;105:24-9.

24. Reichhart JM, Meister M, Dimarcq JL, Zachary D, Hoffmann D, Ruiz C, et al. Insect immunity: developmental and inducible activity of the Drosophila diptericin promoter. EMBO J. 1992;11:1469-77.

25. Lee JH, Kim JH, Hwang SW, Lee WJ, Yoon HK, Lee HS, et al. High-level expression of antimicrobial peptide mediated by a fusion partner reinforcing formation of inclusion bodies. Biochem Biophys Res Commun. 2000:277:575-80

26. Huang L, Leong SSJ, Jiang R. Soluble fusion expression and characterization of bioactive human beta-defensin 26 and 27. Appl Microbiol Biotechnol. 2009:84:301-8.

27. Buckholz RG, Gleeson MA. Yeast systems for the commercial production of heterologous proteins. Nat Biotechnol. 1991;9:1067-72.

28. Cregg JM, VedvickTS, Raschke WC. Recent advances in the expression of foreign genes in Pichia pastoris. Nat Biotechnol. 1993;11:905-10.

29. Li L, Wang J-X, Zhao X-F, Kang C-J, Liu N, Xiang J-H, et al. High level expression, purification, and characterization of the shrimp antimicrobial peptide, Ch-penaeidin, in Pichia pastoris. Protein Expr Purif. 2005:39:144-51.

30. Jin F, Xu X, Wang L, Zhang W, Gu D. Expression of recombinant hybrid peptide cecropinA(1-8)-magainin2(1-12) in Pichia pastoris: purification and characterization. Protein Expr Purif. 2006;50:147-56.

31. Sang $Y-X$, Deng $X-J$, Yang $W-Y$, Wang $W-X$, Wen S-Y, Liu W-Q, et al. Secretive expression of insect antifungal peptide-encoded genes in Pichia pastoris and activity assay of the products. Agric Sci China. 2007:6:1209-16. 
32. Chen Z, Wang D, Cong Y, Wang J, Zhu J, Yang J, et al. Recombinant antimicrobial peptide hPAB- $\beta$ expressed in Pichia pastoris, a potential agent active against methicillin-resistant Staphylococcus aureus. Appl Microbiol Biotechnol. 2011;89:281-91.

33. Robinson TP, Aboaba OO, Kaloti A, Ocio MJ, Baranyi J, Mackey BM. The effect of inoculum size on the lag phase of Listeria monocytogenes. Int J Food Microbiol. 2001;70:163-73.

34. Blondelle SE, Houghten RA. Hemolytic and antimicrobial activities of the twenty-four individual omission analogues of melittin. Biochemistry. 1991;30:4671-8

35. Blondelle SE, Simpkins LR, Pérez-Payá E, Houghten RA. Influence of tryptophan residues on melittin's hemolytic activity. Biochim Biophys Acta (BBA)/Protein Struct Mol. 1993;1202:331-6.

36. Saberwal G, Nagaraj R. Cell-lytic and antibacterial peptides that act by perturbing the barrier function of membranes: facets of their conformational features, structure-function correlations and membraneperturbing abilities. Biochim Biophys Acta (BBA)-Rev Biomembr. 1994;1197:109-31.

37. Maloy WL, Kari UP. Structure-activity studies on magainins and other host-defense peptides. Biopolymers. 1995;37:105-22.
38. Otvos $\mathrm{L}$. The short proline-rich antibacterial peptide family. Cell Mol Life Sci. 2002;59(7):1138-50.

39. Rahnamaeian M, Langen G, Imani J, Khalifa W, Altincicek B, Von Wettstein $D$, et al. Insect peptide metchnikowin confers on barley a selective capacity for resistance to fungal ascomycetes pathogens. J Exp Bot. 2009;60:4105-14.

40. Rahnamaeian M, Vilcinskas A. Defense gene expression is potentiated in transgenic barley expressing antifungal peptide metchnikowin throughout powdery mildew challenge. J Plant Res. 2012;125:115-24.

41. Rahnamaeian M, Cytryńska M, Zdybicka-Barabas A, Vilcinskas A. The functional interaction between abaecin and pore-forming peptides indicates a general mechanism of antibacterial potentiation. Peptides. 2016;78:17-23.

42. Rahnamaeian M, Cytryńska M, Zdybicka-Barabas A, Dobslaff K, Wiesner J, Twyman RM, et al. Insect antimicrobial peptides show potentiating functional interactions against gram-negative bacteria. Proc R Soc Lond B. 2015;282:20150293.

\section{Submit your next manuscript to BioMed Central and we will help you at every step:}

- We accept pre-submission inquiries

- Our selector tool helps you to find the most relevant journal

- We provide round the clock customer support

- Convenient online submission

- Thorough peer review

- Inclusion in PubMed and all major indexing services

- Maximum visibility for your research

Submit your manuscript at www.biomedcentral.com/submit 